\title{
Synthesis of the Sex Pheromone of the Tea Tussock Moth Based on a Resource Chemistry Strategy
}

\author{
Hong-Li Zhang ${ }^{1,+}{ }^{\dagger}$, Zhi-Feng Sun ${ }^{2,3,+}$, Lu-Nan Zhou ${ }^{3}$, Lu Liu ${ }^{3}$, Tao Zhang ${ }^{3, *}$ and \\ Zhen-Ting $\mathrm{Du}^{3,4}$,* (i) \\ 1 State Key Laboratory of Crop Stress Biology in Arid Areas, Northwest A\&F University, Yangling 712100, \\ China; honglizhang@126.com \\ 2 Shaanxi Key Laboratory for Catalysis, College of Chemical and Environment Science, Shaanxi University of \\ Technology, Hanzhong 723001, China; sunzhifeng2018@163.com \\ 3 College of Chemistry and Pharmacy, Northwest A\&F University, Yangling 712100, China; \\ Zhou18792419302@163.com (L.-N.Z.); m18706733265@163.com (L.L.) \\ 4 Key Laboratory of Botanical Pesticide R\&D in Shaanxi Province, Yangling 712100, China \\ * $\quad$ Correspondence: fuzitong@163.com (T.Z.); duzt@nwsuaf.edu.cn (Z.-T.D.); Tel.: +86-29-8709-2662 (Z.-T.D.) \\ $\dagger$ These authors contributed equally to this work.
}

Received: 16 May 2018; Accepted: 3 June 2018; Published: 4 June 2018

\begin{abstract}
Synthesis of the sex pheromone of the tea tussock moth in 33\% overall yield over 10 steps was achieved. Moreover, the chiral pool concept was applied in the asymmetric synthesis. The synthesis used a chemical available on a large-scale from recycling of wastewater from the steroid industry. The carbon skeleton was constructed using the $\mathrm{C} 4+\mathrm{C} 5+\mathrm{C} 8$ strategy. Based on this strategy, the original chiral center was totally retained.
\end{abstract}

Keywords: insect sex pheromone; tea tussock moth; total synthesis; resource chemistry

\section{Introduction}

Today, safer agricultural produce demands that farming procedures be performed in a greener way. In this context, integrated pest management (IPM) is proposed, which is a broad-based approach that integrates practices for the economic control of pests. Among them, using low-dose pheromones to control pest has been accepted by more and more agricutural providers. In East Asia, a kind of pest called tea tussock moth (Euproctis pseudoconspersa) causes huge destruction in tea orchids. The bit leaves may fall off and decrease the gross product. If this kind of pest was controlled by pheromone, the tea leaves could be provided better than before. The main component of the moth's sex pheromone was first reported by Wakamura as 10,14-dimethyl-1-pentadecyl isobutyrate [1,2]. Then, a field attraction attempt was tested using crude extract from females and synthetic pheromones [3], and the result revealed that both $S$ and $R$ configurations have similar luring activities. As continuation of our interest in green agrochemicals [4-7], a synthesis of insect pheromone $\mathbf{1}$ based on a resource chemistry strategy was envisioned. As a matter of fact, there are several synthetic approaches to this compound in the literature. Ichikawa [8] and Zhao [2] synthesized the tussock moth pheromone (R)-1 from (S)-citronellol or its corresponding bromide. Very recently, a synthesis of tussock pheromone based on a protective-group-free strategy [9] has been reported by our group, in which the Evans' template was adopted to control the chirality.

Some 4000 tons of sapogenin are produced every year by the Chinese steroid industry. If a new $\mathrm{H}_{2} \mathrm{O}_{2}$ oxidation procedure were to be applied to pregna-16,20-diol, a large quantity of (5S)-3-hydroxy-5-methyltetrahydro-2H-pyran-2-one (2) could become available, and 1000 tons of chiral material could be recycled. Tian et al. developed a toolkit of chiral building blocks from 
this resource chemical [10] and used it to achieve several syntheses of natural compounds [6,11-13]. He coined the term "resource chemical", which refers to large-scale and useful substances. Herein, we discuss the synthesis of the pheromone of the tea tussock moth based on this resource chemical.

\section{Results and Discussions}

As Scheme 1 shows, the retrosynthesis was based on two Julia coupling reactions, namely a $\mathrm{C} 4+\mathrm{C} 5+\mathrm{C} 8$ strategy. The left hand $\mathrm{C} 4$ synthon was easily obtained, and the right $\mathrm{C} 8$ subunit was a protected aldehyde 3 . The middle unit can be derived from a chiral methyl aldehyde, which is a large-scale resource chemical derivative.

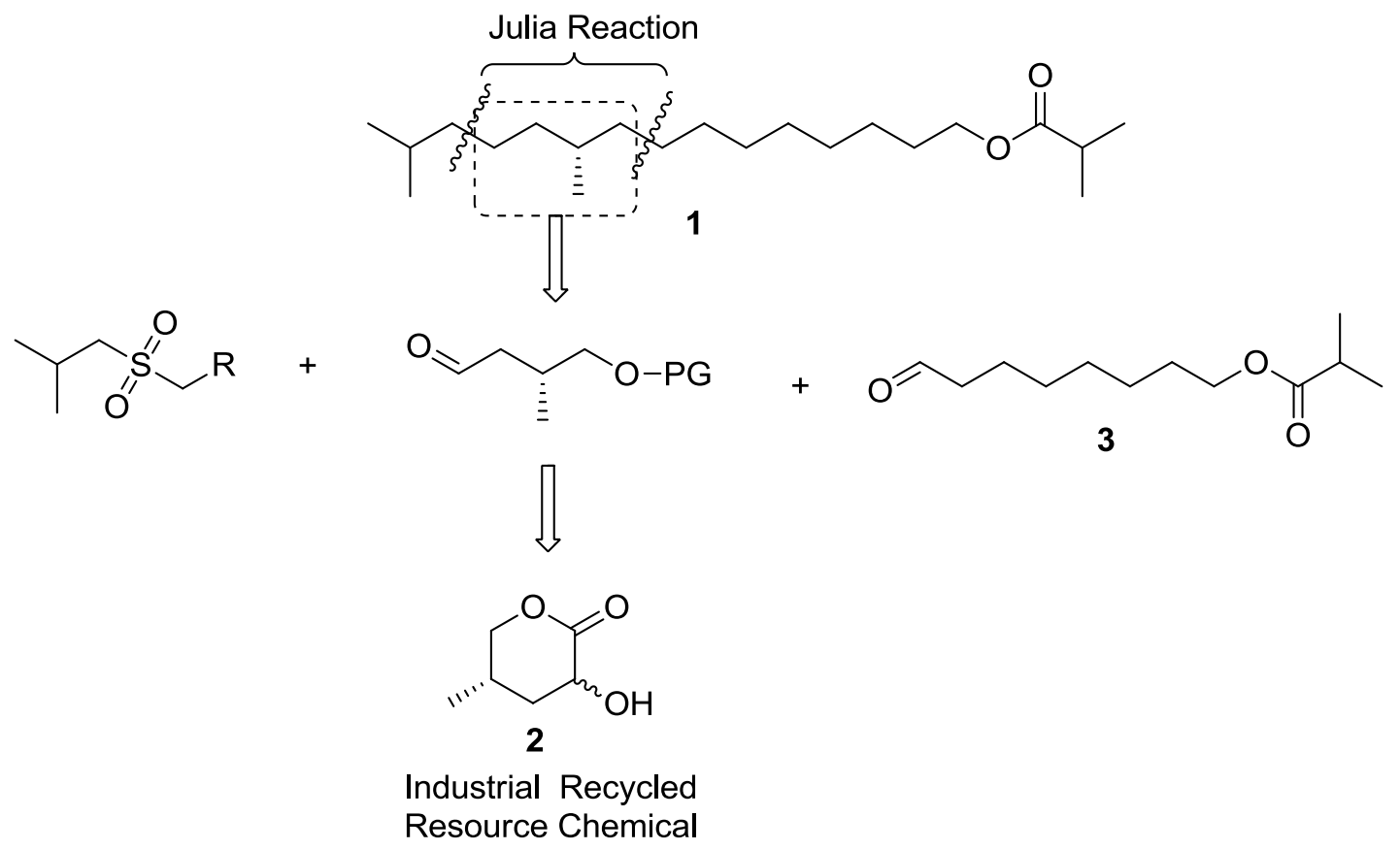

Scheme 1. Retrosynthesis of compound 1 based on Julia olefination and a resource-chemical.

As Scheme 2 shows, the synthesis commenced from chiral lactone 2 which was ring-opened $[14,15]$ under basic conditions and subjected to selective benzylation to give compound 4 . In practice it proved laborious to purify the very polar hydroxyacid, so it was used directly without further purification. To reduce the carboxylic acid effectively, the ethyl ester 5 could be obtained in $75 \%$ yield for two steps under acid-catalyzed esterification conditions [11], but according to the ${ }^{1} \mathrm{H}-\mathrm{NMR}$ and ${ }^{13} \mathrm{C}-\mathrm{NMR}$ spectra (supplementary material), it could be observed that the hydroxyl group in the 2-position was partially epimerized. We suspect this resulted from the basic conditions used. We could observe some small peaks and high peaks with a height ratio of c.a. 1:3. Fortunately, the chirality of the desired methyl group didn't matter. The subsequent reduction by $\mathrm{LiAlH}_{4}$ gave the vicinal diol 6 in $80 \%$ yield, which is a good substrate for an aldehyde. Therefore, the chiral aldehyde (R)-4-(benzyloxy)-3-methylbutanal 7 could be produced in 93\% yield after a conventional oxidative diol cleavage using $\mathrm{NaIO}_{4}$ in aqueous solvent. Several preparation methods of compound 7 that can be found in the literature. Aside from Wei's route [11], the rest require more chemical operations [16], an expensive chiral auxiliary such as the Evans template [17-19] or poisonous cyanide [20]. The e.e. was determined by comparison of the optical rotation value $[\alpha]_{\mathrm{D}}^{25}+10.6\left(c 0.7, \mathrm{CHCl}_{3}\right)$; lit. [17] $[\alpha]_{\mathrm{D}}{ }^{20}+10.4\left(c 0.7, \mathrm{CHCl}_{3}\right)$. Next, at $-78--50{ }^{\circ} \mathrm{C}$, a Julia-Kocienski reaction was performed between 5-(isobutylsulfonyl)-1-phenyl-1H-tetrazole (8), which was prepared according to the literature [21] and the chiral aldehyde 7 , affording the coupling product 9 in $87 \%$ yield ( $E / Z$ ratio of $1: 1$ ). The subsequent hydrogenation of the $\mathrm{C}=\mathrm{C}$ double bond and removal of the benzyl protecting group was achieved 
in one-pot in 86\% yield. (R)-2,6-dimethylheptan-1-ol (10) was converted into a Julia sulfone reagent 12 through the Mitsunobu protocol [22], followed by an oxidative reaction (83\% and 99\% yield, respectively). A Julia-Lythgoe reaction between aldehyde 3 and sulfone 12 gave the corresponding alkene product 13 in $79 \%$ yield with an $E / Z$ ratio of 2:1. To prevent the isomerization and racemization of the chiral center, alkene 13 was subjected to $\mathrm{Pt} / \mathrm{C}$ catalytic hydrogenation [23], giving $(S)-\mathbf{1}$ in $99 \%$ yield. All the analytic data for synthetic compound $\mathbf{1}$ are in accordance with that reported in the literature $[8,9]$.
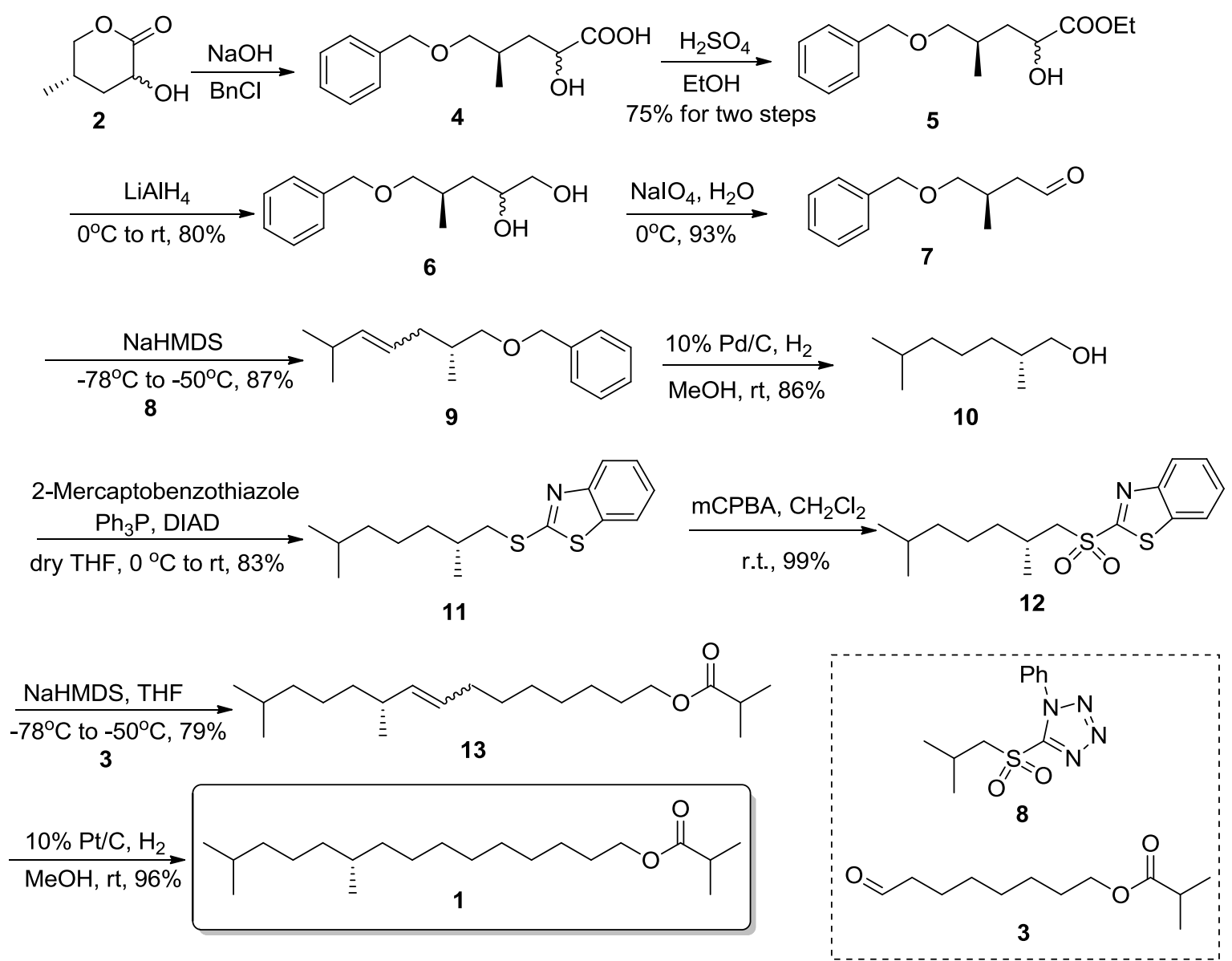

Scheme 2. Synthesis of (S)-1 through a double Julia approach.

As Scheme 3 shows, similar to the literature [9], octane-1,8-diol was esterified selectively with $70 \%$ yield using a stoichiometric amount of isobutyric acid at presence of catalytic sulfuric acid in toluene [24]. Then, a pyridinium chlorochromate (PCC) [25] oxidation was applied, and the aldehyde 3 was produced in $90 \%$ yield (Scheme 3 ).

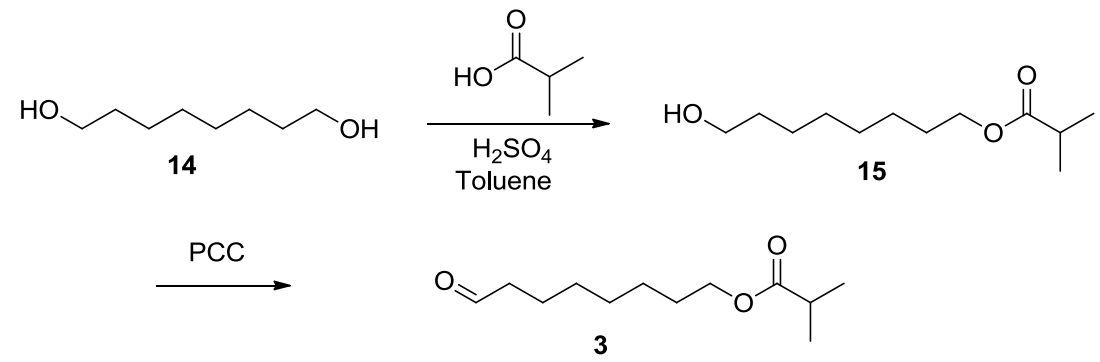

Scheme 3. Synthesis of compound 3. 


\section{Experimental Section}

\subsection{General Methods}

THF was distilled from sodium/benzophenone and $\mathrm{CH}_{2} \mathrm{Cl}_{2}$ was distilled from $\mathrm{CaH}_{2}$ before use. Reactions were monitored by thin-layer chromatography (TLC) on glass plates coated with silica gel with fluorescent indicator. Flash chromatography was performed on silica gel (200-300) with petroleum/EtOAc as the eluent. Optical rotations were measured on a polarimeter with a sodium lamp. HRMS spectra were measured on a LCMS-IT-TOF or LTQ-Orbitrap-XL apparatus. IR spectra were recorded using a Fourier transform infrared spectrometer. NMR spectra were recorded on a AC-500 MHz instrument (Bruker, Madison, WI, USA). Chemical shifts were reported in $\delta(\mathrm{ppm})$ and referenced to an internal TMS standard for ${ }^{1} \mathrm{H}-\mathrm{NMR}$ and $\mathrm{CDCl}_{3}$ (77.16 ppm) for ${ }^{13} \mathrm{C}$ - NMR (Supplementary material).

\subsection{Ethyl (4R)-5-(Benzyloxy)-2-Hydroxy-4-Methylpentanoate (5)}

The raw material 2 was obtained from the Pharmaceutical Factory of Shaanxi Academy of Science, Yangling, China as a strong basic, aqueous solution. If the water was removed, a large-scale raw (70-75\% purity) brown solid could be obtained. In this paper, this solution was acidified to $\mathrm{pH}=1$, filtered, and the filtrate was extracted with ethyl acetate to afford crude 2. Compound 2 was purified through column chromatography. Because the straight separation of 2 from proved laborious, the raw lactone 2 was used directly sometimes to save time.

To purified lactone $2(6.5 \mathrm{~g}, 50 \mathrm{mmol})$, toluene $(100 \mathrm{~mL})$ and powdered $\mathrm{NaOH}(8 \mathrm{~g}, 200 \mathrm{mmol})$ were added. After the mixture was refluxed for $6 \mathrm{~h}$, at the same time, the produced water was removed through a Dean-Stark trap, and then $\mathrm{BnCl}(15.8 \mathrm{~g}, 125 \mathrm{mmol})$ was added in 3-5 batches, and the reaction mixture was allowed to react for another $12 \mathrm{~h}$. Then, water $(100 \mathrm{~mL})$ was added, and the aqueous phase was extracted with $\mathrm{Et}_{2} \mathrm{O}(70 \mathrm{~mL} \times 3)$. The organic phases were discarded, and the aqueous phase was acidified with concentrated hydrochloric acid to $\mathrm{pH}=1$. The resulting aqueous phase was extracted with EtOAc $(70 \mathrm{~mL} \times 3)$, and the combined organic layers were dried over $\mathrm{MgSO}_{4}$, filtered, and concentrated to give the crude acid without further purification. The above crude acid was dissolved in $\mathrm{EtOH}(150 \mathrm{~mL})$, and then $\mathrm{H}_{2} \mathrm{SO}_{4}(5.00 \mathrm{~mL}, 98 \%)$ was added dropwise. After the mixture was refluxed for $4 \mathrm{~h}$, it was monitored by TLC. Then, the reaction was dispensed into EtOAc $(250 \mathrm{~mL})$, and washed with water, saturated $\mathrm{NaHCO}_{3}$, and brine. The solvent was evaporated, and the residue was purified through column chromatography to give the ester 5 with partly epimerized hydroxyl group $8.9 \mathrm{~g}$ as a yellowish oil. IR (film) $\nu_{\max } 3450,2958,2851,2359,1737,1458,1211,1092$, 740, $701 \mathrm{~cm}^{-1}$; ${ }^{1} \mathrm{H}-\mathrm{NMR}\left(500 \mathrm{MHz}, \mathrm{CDCl}_{3}\right) \delta 7.33-7.37(\mathrm{~m}, 5 \mathrm{H}), 4.22-4.35(\mathrm{~m}, 3 \mathrm{H}), 3.30-3.40(\mathrm{~m}, 1 \mathrm{H})$, $3.31-3.38(\mathrm{~m}, 2 \mathrm{H}), 2.04-2.14(\mathrm{~m}, 1 \mathrm{H}), 1.62-1.77(\mathrm{~m}, 2 \mathrm{H}), 1.29(\mathrm{t}, J=7.1 \mathrm{~Hz}, 2 \mathrm{H}), 1.05(\mathrm{~d}, J=6.8 \mathrm{~Hz}, 3 \mathrm{H})$; ${ }^{13} \mathrm{C}-\mathrm{NMR}\left(125 \mathrm{MHz}, \mathrm{CDCl}_{3}\right) \delta 175.4,138.2,130.2,128.4,127.6,75.8,73.1,69.3,61.5$ 39.3, 30.6, 16.8, 14.2.

\section{3. (R)-4-(Benzyloxy)-3-Methylbutanal (7)}

To a suspension of LAH $(1.11 \mathrm{~g}, 30.0 \mathrm{mmol})$ in THF $(45 \mathrm{~mL})$, a solution of ester 5 ( $5.2 \mathrm{~g}, 19.5 \mathrm{mmol})$ in THF $(10 \mathrm{~mL})$ was added dropwise in an ice bath. The reaction mixture was warmed to r.t after being stirred for $3 \mathrm{~h}$, followed by another stirring for $10 \mathrm{~h}$. The resulting mixture was carefully quenched with water $(1 \mathrm{~mL})$ and aqueous $\mathrm{NaOH}(5 \%, 2 \mathrm{~mL})$, and the precipitated salt was filtered. The cake was washed with THF $(30 \mathrm{~mL})$, combined with the filtrate, and concentrated to give the crude diol without further purification. From the crude NMR, we could see there were two diastereomers in ca 1:3. At $0{ }^{\circ} \mathrm{C}$, to diol $6(1.2 \mathrm{~g} 5 \mathrm{mmol})$ in water $(20 \mathrm{~mL})$, sulfuric acid was added to $\mathrm{pH}=6$. Then $\mathrm{NaIO}_{4}$ $(1.6 \mathrm{~g}, 7.5 \mathrm{mmol})$ was added portionwise and the resulting mixture was stirred for $1.5 \mathrm{~h}$. After the reaction was complete, the mixture was extracted with $\mathrm{Et}_{2} \mathrm{O}(30 \mathrm{~mL} \times 3)$, and the combined organic layers were washed with brine. The extract was dried, filtrated, and concentrated to give the aldehyde 7 as a colorless oil with $87 \%$ yield in two steps. $[\alpha]_{\mathrm{D}}{ }^{25}+10.6\left(c\right.$ o.7, $\left.\mathrm{CHCl}_{3}\right) ;{ }^{1} \mathrm{H}-\mathrm{NMR}\left(500 \mathrm{MHz}, \mathrm{CDCl}_{3}\right)$ $\delta: 9.80(\mathrm{t}, 1 \mathrm{H}, J=3.2 \mathrm{~Hz}), 7.32-7.41(\mathrm{~m}, 5 \mathrm{H}), 4.53(\mathrm{~s}, 2 \mathrm{H}), 3.42(\mathrm{dd}, J=9.1,5.2 \mathrm{~Hz}, 1 \mathrm{H}), 3.26(\mathrm{dd}, J=9.1$, $7.7 \mathrm{~Hz}, 1 \mathrm{H}), 2.56(\mathrm{ddd}, J=16.2,6.3,2.3 \mathrm{~Hz}, 1 \mathrm{H}), 2.30-2.44(\mathrm{~m}, 1 \mathrm{H}), 2.28(\mathrm{ddd}, J=16.2,7.0,2.1 \mathrm{~Hz}, 1 \mathrm{H})$, 
$0.99(\mathrm{~d}, J=6.8 \mathrm{~Hz}, 3 \mathrm{H}) ;{ }^{13} \mathrm{C}-\mathrm{NMR}\left(125 \mathrm{MHz}, \mathrm{CDCl}_{3}\right) \delta: 202.4,138.3,128.4,127.6,127.6,74.9,73.1,48.5$, 29.2, 17.1.

\section{4. (2R)-(((2,6-Dimethylhept-4-en-1-yl)oxy)Methyl)Benzene (9)}

To a stirred solution of compound $8(2.4 \mathrm{~g}, 8.9 \mathrm{mmol})$ in THF $(30.0 \mathrm{~mL})$ at $-78{ }^{\circ} \mathrm{C}$ under argon, NaHMDS (2.0 M in THF, $5.60 \mathrm{~mL}, 11.3 \mathrm{mmol}$ ) was added dropwise. After $30 \mathrm{~min}$, a solution of compound $7(1.4 \mathrm{~g}, 7.26 \mathrm{mmol})$ in THF $(10.0 \mathrm{~mL})$ was added dropwise. Upon stirring at $-78{ }^{\circ} \mathrm{C}$ for $2 \mathrm{~h}$, the reaction was warmed to $-50^{\circ} \mathrm{C}$ overnight. After the reaction was quenched with saturated aqueous $\mathrm{NH}_{4} \mathrm{Cl}$ at $-50^{\circ} \mathrm{C}$, it was extracted with ethyl acetate, washed with brine, dried over anhydrous $\mathrm{Na}_{2} \mathrm{SO}_{4}$, concentrated, and purified by flash chromatography on silica gel (hexanes: ethyl acetate $=$ $20: 1)$ to give $E / Z$ ca. $1: 1$ mixture of compound 9 as a pale-yellow oil $(1.9 \mathrm{~g}, 87 \%)$. $[\alpha]_{\mathrm{D}}{ }^{25}+1.32(c 2.5$, $\left.\mathrm{CHCl}_{3}\right) .{ }^{1} \mathrm{H}-\mathrm{NMR}\left(500 \mathrm{MHz}, \mathrm{CDCl}_{3}\right) \delta 7.34-7.25(\mathrm{~m}, 5 \mathrm{H}), 5.37-5.22(\mathrm{~m}, 2 \mathrm{H}), 4.5(\mathrm{~d}, J=2.5 \mathrm{~Hz}, 2 \mathrm{H})$, 3.36-3.23 (m, 2H), 2.6-2.11 (m, 2H), 1.96-1.79 (m, 2H), 0.96-0.9 (m, 9H); ${ }^{13} \mathrm{C}-\mathrm{NMR}\left(125 \mathrm{MHz}, \mathrm{CDCl}_{3}\right) \delta$ 139.4, 138.7, 128.3, 127.6, 127.6, 127.4, 125.2, 124.8, 75.5, 75.4, 73.0, 73.0, 36.6, 34.0, 33.8, 31.3, 31.1, 26.4, $23.1,23.1,22.7,22.7,17.0,16.8$.

\section{5. (R)-2,6-dimethylheptan-1-ol (10)}

To a solution of ether $9(1.6 \mathrm{~g}, 6.89 \mathrm{mmol})$ in methanol $(50 \mathrm{~mL}), \mathrm{Pd} / \mathrm{C}(10 \%, 0.3 \mathrm{~g})$ was added and the atmosphere was exchanged with $\mathrm{H}_{2}$. The reaction mixture was stirred for $24 \mathrm{~h}$ and monitored by TLC. After completion, the catalyst was filtered through a Celite pad, and the filtrate was evaporated, giving compound 10 after flash column purification as a pale-yellow oil $(0.85 \mathrm{~g}, 86 \%)$. $[\alpha]_{\mathrm{D}}{ }^{25}+4.68(c$ 2.4, $\left.\mathrm{CHCl}_{3}\right) .{ }^{1} \mathrm{H}-\mathrm{NMR}\left(500 \mathrm{MHz}, \mathrm{CDCl}_{3}\right) \delta 3.53-3.49(\mathrm{~m}, 1 \mathrm{H}), 3.44-3.39(\mathrm{~m}, 1 \mathrm{H}), 1.61(\mathrm{~s}, 1 \mathrm{H}), 1.56-1.51$ $(\mathrm{m}, 1 \mathrm{H}), 1.36-1.08(\mathrm{~m}, 7 \mathrm{H}), 0.92(\mathrm{~d}, J=6.6 \mathrm{~Hz}, 3 \mathrm{H}), 0.87(\mathrm{~d}, J=6.4 \mathrm{~Hz}, 6 \mathrm{H}) ;{ }^{13} \mathrm{C}-\mathrm{NMR}\left(125 \mathrm{MHz}, \mathrm{CDCl}_{3}\right)$ $\delta 68.4,35.8,33.4,27.9,24.7,22.7,22.6,16.6$.

\section{6. (R)-2-((2,6-Dimethylheptyl)thio)Benzo[d]Thiazole (11)}

Under argon, to a flask with (R)-2,6-dimethylheptan-1-ol $10(0.7 \mathrm{~g}, 4.85 \mathrm{mmol})$, THF (25 mL), benzo[d]thiazole-2-thiol $(1.0 \mathrm{~g}, 6.0 \mathrm{mmol})$, and TPP $(1.5 \mathrm{~g}$, $6.0 \mathrm{mmol})$ were added. To this mixture, DIAD $(1.1 \mathrm{~mL}, 6.0 \mathrm{mmol})$ was added dropwise at $0{ }^{\circ} \mathrm{C}$. After the reaction was completed, the volatile was evaporated, and the residue was purified through column chromatography to give compound 11 (1.2 g, 83\% yield). [ $\alpha]_{\mathrm{D}}{ }^{25}-3.63\left(c 3.1, \mathrm{CHCl}_{3}\right) .{ }^{1} \mathrm{H}-\mathrm{NMR}\left(500 \mathrm{MHz}, \mathrm{CDCl}_{3}\right) \delta 7.9(\mathrm{~d}, J=8.1 \mathrm{~Hz}, 1 \mathrm{H}), 7.79$ $(\mathrm{d}, J=8 \mathrm{~Hz}, 1 \mathrm{H}), 7.45(\mathrm{t}, J=7.3 \mathrm{~Hz}, 1 \mathrm{H}), 7.33(\mathrm{t}, J=7.3 \mathrm{~Hz}, 1 \mathrm{H}), 3.48-3.22(\mathrm{~m}, 2 \mathrm{H}), 2.01-1.95(\mathrm{~m}, 1 \mathrm{H})$, 1.6-1.3 (m, 5H), 1.24-1.2 (m, 2H), $1.12(\mathrm{~d}, J=6.7 \mathrm{~Hz}, 3 \mathrm{H}), 0.92(\mathrm{~d}, J=6.6 \mathrm{~Hz}, 6 \mathrm{H}) ;{ }^{13} \mathrm{C}-\mathrm{NMR}(125 \mathrm{MHz}$, $\left.\mathrm{CDCl}_{3}\right) \delta 167.79,153.38,135.19,126.0,124.09,121.45,120.91,40.78,39.06,36.35,33.3,27.95,24.69,22.71$, 22.6, 19.4. HRMS (ESI) $m / z$ calcd. for $\mathrm{C}_{16} \mathrm{H}_{24} \mathrm{NO}_{2} \mathrm{~S}_{2}{ }^{+}(\mathrm{M}+\mathrm{H})^{+}$: 326.1248, found 326.1245 .

\section{7. (R)-2-((2,6-Dimethylheptyl)Sulfonyl)Benzo[d]Thiazole (12)}

To a solution of compound $11(1.0 \mathrm{~g}, 3.61 \mathrm{mmol})$ in $\mathrm{CH}_{2} \mathrm{Cl}_{2}(35 \mathrm{~mL}), m \mathrm{CPBA}(4.7 \mathrm{~g}, 70 \%, 5.6 \mathrm{eq})$ was added, and the reaction mixture was stirred for $12 \mathrm{~h}$ at r.t. Then, saturated $\mathrm{Na}_{2} \mathrm{~S}_{2} \mathrm{O}_{3}$ was added to quench the reaction, and the reaction was neutralized using saturated $\mathrm{Na}_{2} \mathrm{CO}_{3}$ and extracted with

$\mathrm{CH}_{2} \mathrm{Cl}_{2}$. The combined organic layers were washed with brine, and the extract was dried over $\mathrm{MgSO}_{4}$, filtrated, and concentrated to give compound 12 as a colorless oil with $99 \%$ yield. $[\alpha]_{\mathrm{D}}{ }^{25}-2.99$ (c 2.6, $\left.\mathrm{CHCl}_{3}\right) .{ }^{1} \mathrm{H}-\mathrm{NMR}\left(500 \mathrm{MHz}, \mathrm{CDCl}_{3}\right) \delta 8.21(\mathrm{~d}, J=8.0 \mathrm{~Hz}, 1 \mathrm{H}), 8.01(\mathrm{~d}, J=7.6 \mathrm{~Hz}, 1 \mathrm{H}), 7.66-7.58(\mathrm{~m}$, $2 \mathrm{H}), 3.56(\mathrm{dd}, J=14.3,4.7 \mathrm{~Hz}, 1 \mathrm{H}), 3.35(\mathrm{dd}, J=14.3,8.0 \mathrm{~Hz}, 1 \mathrm{H}), 2.31-2.25(\mathrm{~m}, 1 \mathrm{H}), 1.49-1.43(\mathrm{~m}, 2 \mathrm{H})$, $1.34-1.25(\mathrm{~m}, 3 \mathrm{H}), 1.14(\mathrm{~d}, J=6.7 \mathrm{~Hz}, 3 \mathrm{H}), 1.11-1.06(\mathrm{~m}, 2 \mathrm{H}), 0.82(\mathrm{~d}, J=6.5,3 \mathrm{H}), 0.81(\mathrm{~d}, J=6.5 \mathrm{~Hz}, 3 \mathrm{H})$; ${ }^{13} \mathrm{C}-\mathrm{NMR}\left(125 \mathrm{MHz}, \mathrm{CDCl}_{3}\right) \delta 166.83,152.76,136.79,127.98,127.64,125.46,122.37,60.83,38.7,36.89$, $28.57,27.84,24.08,22.57,22.49,19.91$. HRMS (ESI) $m / z$ calcd. for $\mathrm{C}_{16} \mathrm{H}_{24} \mathrm{NO}_{2} \mathrm{~S}_{2}{ }^{+}(\mathrm{M}+\mathrm{H})^{+}: 326.1248$, found 326.1245 . 


\subsection{8-Hydroxyoctyl Isobutyrate $\mathbf{1 5}$}

To a solution of octane-1,8-diol $(7.3 \mathrm{~g}, 50 \mathrm{mmol})$ and isobutyric acid ( $4.2 \mathrm{~g}, 48 \mathrm{mmol})$ in toluene $(100 \mathrm{~mL})$, four drops of concentrated sulfuric acid were added, and the reaction mixture was warmed to $75{ }^{\circ} \mathrm{C}$ for $20 \mathrm{~h}$. The reaction mixture was diluted using ethyl acetate $(200 \mathrm{~mL})$ and washed with water, $\mathrm{NaHCO}_{3}$, and brine, then dried over $\mathrm{MgSO}_{4}$. The solvent was evaporated, and the residue was purified through column chromatography to give compound $15(8.8 \mathrm{~g}, 85 \%)$ as a colorless oil. ${ }^{1} \mathrm{H}$ $\operatorname{NMR}\left(500 \mathrm{MHz}, \mathrm{CDCl}_{3}\right) \delta 4.04(\mathrm{t}, J=6.7 \mathrm{~Hz}, 2 \mathrm{H}), 3.62(\mathrm{t}, J=6.6 \mathrm{~Hz}, 2 \mathrm{H}), 2.55-2.49(\mathrm{~m}, 1 \mathrm{H}), 2.03(\mathrm{~s}, 1 \mathrm{H})$, 1.62-1.52 (m, 4H), $1.32(\mathrm{~s}, 8 \mathrm{H}), 1.15(\mathrm{~d}, J=7.0 \mathrm{~Hz}, 6 \mathrm{H}) ;{ }^{13} \mathrm{C}-\mathrm{NMR}\left(125 \mathrm{MHz}, \mathrm{CDCl}_{3}\right) \delta 177.26,64.31$, $62.93,34.02,32.70,29.24,29.15,28.59,25.79,25.62,18.97$.

\subsection{8-Oxo-Octyl Isobutyrate (3)}

To a solution of 8-hydroxyoctyl isobutyrate $15(2.8 \mathrm{~g}, 13 \mathrm{mmol})$ in $\mathrm{CH}_{2} \mathrm{Cl}_{2}(30 \mathrm{~mL})$, silica gel (200 mesh, $2 \mathrm{~g})$ and PCC (4.2 g, $19.5 \mathrm{mmol})$ were added. The above reaction mixture was stirred overnight, followed by the addition of ether $(50 \mathrm{~mL})$. Then, the solution of crude aldehyde was decanted and purified through flash column chromatography to give 8-oxooctyl isobutyrate 3 (2.6 g, 94\%) as a colorless oil. ${ }^{1} \mathrm{H}-\mathrm{NMR}\left(500 \mathrm{MHz}, \mathrm{CDCl}_{3}\right) \delta 9.76(\mathrm{t}, J=1.8 \mathrm{~Hz}, 1 \mathrm{H}), 4.05(\mathrm{t}, J=6.7 \mathrm{~Hz}, 2 \mathrm{H})$, 2.56-2.50 (m, 1H), $2.42(\mathrm{td}, J=1.7,7.3 \mathrm{~Hz}, 2 \mathrm{H}), 1.64-1.61(\mathrm{~m}, 4 \mathrm{H}), 1.34(\mathrm{~s}, 6 \mathrm{H}), 1.15(\mathrm{~d}, J=7.0 \mathrm{~Hz}, 6 \mathrm{H})$; ${ }^{13} \mathrm{C}-\mathrm{NMR}\left(125 \mathrm{MHz}_{\mathrm{CDCl}}\right) \delta$ 202.69, 177.22, 64.22, 43.83, 34.02, 29.0, 28.95, 28.55, 25.69, 21.94, 18.99 .

\subsection{0. (R)-10,14-Dimethylpentadec-8-en-1-yl Isobutyrate (13)}

Under argon, NaHMDS (1.6 mL, 2.0 M in THF, $3.2 \mathrm{mmol})$ was added dropwise to a solution of compound $12(0.8 \mathrm{~g}, 2.5 \mathrm{mmol})$ in anhydrous THF $(25 \mathrm{~mL})$ at $-78^{\circ} \mathrm{C}$. After half an hour, 8-oxooctyl isobutyrate $3(0.7 \mathrm{~g}, 3.3 \mathrm{mmol})$ in THF $(10 \mathrm{~mL})$ was added. The reaction mixture was stirred under the same temperature for $3 \mathrm{~h}$, followed by stirring for another $12 \mathrm{~h}$ at $-50{ }^{\circ} \mathrm{C}$. After the reaction was quenched with saturated aqueous $\mathrm{NH}_{4} \mathrm{Cl}$ at $-50{ }^{\circ} \mathrm{C}$, it was extracted with ethyl acetate, washed with brine, dried over anhydrous $\mathrm{Na}_{2} \mathrm{SO}_{4}$, concentrated, and purified by flash chromatography on silica gel (hexanes: ethyl acetate $=30: 1)$ to give compound 13 as a pale-yellow oil $(0.6 \mathrm{~g}, 79 \%)$. $[\alpha]_{\mathrm{D}}{ }^{25}+3.06$ (c 2.5, $\left.\mathrm{CHCl}_{3}\right) .{ }^{1} \mathrm{H}-\mathrm{NMR}\left(500 \mathrm{MHz}, \mathrm{CDCl}_{3}\right) \delta 7.33-7.25(\mathrm{~m}, 5 \mathrm{H}), 5.36-5.08(\mathrm{~m}, 2 \mathrm{H}), 4.49-4.44(\mathrm{~m}, 2 \mathrm{H})$, 4.06-4.03 (m, 2H), 3.49-3.39 (m, 2H), 2.65-2.5 (m, 2H), 2.07-1.93 (m, 2H), 1.7-1.43 (m, 4H), $1.3(\mathrm{~s}, 8 \mathrm{H})$, $1.16(\mathrm{~d}, J=7.0 \mathrm{~Hz}, 6 \mathrm{H}), 0.98-0.95(\mathrm{~m}, 3 \mathrm{H}) ;{ }^{13} \mathrm{C}-\mathrm{NMR}\left(125 \mathrm{MHz}, \mathrm{CDCl}_{3}\right) \delta 177.25,138.76,138.73,135.53$, $129.05,128.34,127.66,127.61,127.47,72.99,68.82,64.4,37.28,34.08,29.85,29.25,29.19,28.68,28.61$, $27.43,25.93,25.9,21.51,19.05$.

\subsection{1. (S)-10,14-Dimethylpentadecyl Isobutyrate (1)}

To a solution of compound $13(0.3 \mathrm{~g}, 9.3 \mathrm{mmol})$ in ethanol $(15 \mathrm{~mL}), \mathrm{Pt} / \mathrm{C}(10 \%, 6 \mathrm{mg})$ was added and the atmosphere was exchanged with $\mathrm{H}_{2}$. The reaction mixture was then stirred for $24 \mathrm{~h}$ and monitored by TLC. After completion, the catalyst was filtered through a Celite pad, and the filtrate was evaporated. The residue was purified by flash chromatography on silica gel $(\mathrm{PE} / \mathrm{EA}=30: 1)$ to give compound $1(0.28 \mathrm{~g}, 93 \%)$ as a colorless oil: $[\alpha]_{\mathrm{D}}{ }^{25}-0.28\left(\right.$ c $\left.2.4, \mathrm{CHCl}_{3}\right) .{ }^{1} \mathrm{H}-\mathrm{NMR}\left(500 \mathrm{MHz}, \mathrm{CDCl}_{3}\right) \delta$ $4.05(\mathrm{t}, J=6.8 \mathrm{~Hz}, 2 \mathrm{H}), 2.56-2.5(\mathrm{~m}, 1 \mathrm{H}), 1.65-1.59(\mathrm{~m}, 2 \mathrm{H}), 1.55-1.5(\mathrm{~m}, 1 \mathrm{H}), 1.36-1.19(\mathrm{~m}, 17 \mathrm{H}), 1.16(\mathrm{~d}$, $J=7.1 \mathrm{~Hz}, 6 \mathrm{H}), 1.15-1.04(\mathrm{~m}, 4 \mathrm{H}), 0.85(\mathrm{dd}, J=6.7,13.2 \mathrm{~Hz}, 9 \mathrm{H}) ;{ }^{13} \mathrm{C}-\mathrm{NMR}\left(500 \mathrm{MHz}, \mathrm{CDCl}_{3}\right) \delta 177.26$, $64.42,39.4,37.34,37.12,34.08,32.79,30.0,29.62,29.55,29.27,28.68,28.00,27.09,25.93,24.82,22.73,22.64$, 19.73, 19.03. HRMS (ESI) $m / z$ calcd. for $\mathrm{C}_{21} \mathrm{H}_{43} \mathrm{O}_{2}{ }^{+}(\mathrm{M}+\mathrm{H})^{+}: 327.32576$, found 327.32599 .

\section{Conclusions}

Based on a chiral pool strategy, an efficient synthesis of (S)-10,14-dimethylpentadecyl isobutyrate, the sex pheromone of the tea tussock moth, was achieved. The longest linear synthetic step was 10 steps, and the overall yield was 33\%. The key step was accomplished by a double Julia coupling. This synthesis will be helpful in research involving the differences between the biological effects of $R-1$ 
and S-1. The scale-up and evaluation of the biological activities of the sex pheromone is currently under investigation.

Supplementary Materials: Supplementary Materials are available online.

Author Contributions: T.Z. and Z.-T.D. conceived and designed the experiments; Z.-F.S. and L.-N.Z. performed the experiments; H.-L.Z. and L.L. analyzed the data. Z.-T.D. wrote the paper.

Acknowledgments: Partial financial support from the National Natural Science Foundation of China (31301712, 21502151,) is greatly appreciated. Zhen-Ting Du would like to thank Opening Funds of Key Laboratory of Synthetic Chemistry of Natural Substances, Shanghai Institute of Organic Chemistry, Chinese Academy of Sciences for the partial financial support for funding this project.

Conflicts of Interest: The authors declare no conflict of interest.

\section{References}

1. Wakamura, S.; Yasuda, T.; Ichikawa, A.; Fukumoto, T.; Mochizuki, F. Sex attractant pheromone of the tea tussock moth (Euproctis pseudoconspersa): Identification and field attraction. Appl. Entomol. Zool. 1994, 29, 403-411. [CrossRef]

2. Zhao, C.-H.; Millar, J.G.; Pan, K.-H.; Xu, C.-S. Responses of tea tussock moth, Euproctis pseudoconspersa, to its pheromone, $(R)$-10,14-dimethylpentadecyl isobutyrate, and to the S-enantiomer of its pheromone. J. Chem. Ecol. 1998, 24, 1347-1353. [CrossRef]

3. Wang, Y.; Ge, F.; Liu, X.; Feng, F.; Wang, L. Evaluation of mass-trapping for control of tea tussock moth Euproctis pseudoconspersa (Strand) (Lepidoptera: Lymantriidae) with synthetic sex pheromone in south China. Int. J. Pest Manag. 2005, 51, 291-298.

4. Yan, Z.; Guan, C.; Yu, Z.; Tian, W. Fluoroalkanosulfonyl fluorides-mediated cyclodehydration of beta-hydroxy sulfonamides and beta-hydroxy thioamides to the corresponding aziridines and thiazolines. Tetrahedron Lett. 2013, 54, 5788-5790. [CrossRef]

5. Zhang, T.; Feng, J.; Cai, C.; Zhang, X. Synthesis and Field Test of Three Candidates for Soybean Pod Borer's Sex Pheromone. Nat. Prod. Commun. 2011, 6, 1323-1326. [PubMed]

6. Wang, Z.; Xu, Q.; Tian, W.; Pan, X. Stereoselective synthesis of (2S,3S,7S)-3,7-dimethylpentadec-2-yl acetate and propionate, the sex pheromones of pine sawflies. Tetrahedron Lett. 2007, 48, 7549-7551. [CrossRef]

7. Sun, Z.-F.; Zhou, L.-N.; Zhang, T.; Du, Z.-T. Stereoselective synthesis of the Paulownia bagworm sex pheromone. Chin. Chem. Lett. 2017, 28, 558-562. [CrossRef]

8. Ichikawa, A.; Yasuda, T.; Wakamura, S. Absolute configuration of sex pheromone for tea tussock moth, Euproctis pseudoconspersa (strand) via synthesis of $(R)$ - and (S)-10,14-dimethyl-1-pentadecyl isobutyrates. J. Chem. Ecol. 1995, 21, 627-634. [CrossRef] [PubMed]

9. Sun, Z.-F.; Zhou, L.-N.; Meng, Y.; Zhang, T.; Du, Z.-T.; Zheng, H. Concise asymmetric synthesis of the sex pheromone of the tea tussock moth. Tetrahedron Asymmetry 2017, 28, 1562-1567. [CrossRef]

10. Tian, W.S.; Wang, Z.K.; Li, B.; Xu, Q.-H. Synthesis of Thioketal and Application in Synthesis of Optical Pure Diahrotica Undecimpunctata Sex Pheromone. Patent No. CN 101050211, 10 May 2007.

11. Mao, Z.-Y.; Si, C.-M.; Liu, Y.-W.; Dong, H.-Q.; Wei, B.-G.; Lin, G.-Q. Divergent Synthesis of Revised Apratoxin E, 30-epi-Apratoxin E, and 30S/30R-Oxoapratoxin E. J. Org. Chem. 2017, 82, 10830-10845. [CrossRef] [PubMed]

12. Wang, Z.-K.; Tian, W.-S.; Pan, X.-F. Practical synthesis of the main sex pheromones of pine sawflies (2S,3S,7S)-3,7-dimethylpentadecan-2-ol esters by utilizing $(R)$-4-methyl-delta-valerolactone obtained from the industrial waste. Acta Chim. Sin. 2007, 65, 705-710.

13. Wang, Z.-K.; Tian, W.-S.; Pan, X.-F. A concise synthesis of the sex pheromones of Pine sawflies. Chin. J. Org. Chem. 2007, 27, 866-869.

14. Chung, J.; Kushner, A.M.; Weisman, A.C.; Guan, Z. Direct correlation of single-molecule properties with bulk mechanical performance for the biomimetic design of polymers. Nat. Mater. 2014, 13, 1055-1062. [CrossRef] [PubMed]

15. Zhang, L.; Zhu, L.; Yang, J.; Luo, J.; Hong, R. Stereoselective $\alpha$-Hydroxylation of Amides Using Oppolzer's Sultam as Chiral Auxiliary. J. Org. Chem. 2016, 81, 3890-3900. [CrossRef] [PubMed] 
16. Schmid, R.; Hansen, H.J. Synthesis of optically active bifunctional isoprenoid building blocks by rhodium(I)-catalyzed asymmetric allylamine to enamine isomerization. Helv. Chim. Acta 1990, 73, 1258-1275. [CrossRef]

17. Chorley, D.F.; Chen, J.L.-Y.; Furkert, D.P.; Sperry, J.; Brimble, M.A. Total synthesis of danshenspiroketallactone. Synlett 2012, 23, 128-130.

18. Hansen, D.B.; Starr, M.-L.; Tolstoy, N.; Joullie, M.M. A stereoselective synthesis of $(2 S, 4 R)-\delta$-hydroxyleucine methyl ester: A component of cyclomarin A. Tetrahedron Asymmetry 2005, 16, 3623-3627. [CrossRef]

19. Jones, T.K.; Reamer, R.A.; Desmond, R.; Mills, S.G. Chemistry of tricarbonyl hemiketals and application of Evans technology to the total synthesis of the immunosuppressant (-)-FK-506. J. Am. Chem. Soc. 1990, 112, 2998-3017. [CrossRef]

20. Ghosh, A.K.; Wang, Y.; Kim, J.T. Total Synthesis of Microtubule-Stabilizing Agent (-)-Laulimalide. J. Org. Chem. 2001, 66, 8973-8982. [CrossRef] [PubMed]

21. DiBlasi, C.M.; Macks, D.E.; Tan, D.S. An Acid-Stable tert-Butyldiarylsilyl (TBDAS) Linker for Solid-Phase Organic Synthesis. Org. Lett. 2005, 7, 1777-1780. [CrossRef] [PubMed]

22. Mitsunobu, O. The Use of Diethyl Azodicarboxylate and Triphenylphosphine in Synthesis and Transformation of Natural Products. Synthesis 1981, 1981, 1-28. [CrossRef]

23. Li, N.-S.; Scharf, L.; Adams, E.J.; Piccirilli, J.A. Highly Stereocontrolled Total Synthesis of $\beta$-D-Mannosyl Phosphomycoketide: A Natural Product from Mycobacterium tuberculosis. J. Org. Chem. 2013, 78, 5970-5986. [CrossRef] [PubMed]

24. Li, J.-M.; Yong, J.-P.; Huang, F.-L.; Bai, S.-Z. A facile synthesis of the sex pheromone of Grapholitha molesta. Chem. Nat. Compd. 2012, 48, 103-105. [CrossRef]

25. Corey, E.J.; Suggs, J.W. Pyridinium chlorochromate. An efficient reagent for oxidation of primary and secondary alcohols to carbonyl compounds. Tetrahedron Lett. 1975, 16, 2647-2650. [CrossRef]

Sample Availability: Samples of the compounds from 1 to 15 are available from the authors.

(C) 2018 by the authors. Licensee MDPI, Basel, Switzerland. This article is an open access article distributed under the terms and conditions of the Creative Commons Attribution (CC BY) license (http://creativecommons.org/licenses/by/4.0/). 